\title{
Impact of College Provided Transportation on the Absenteeism and Academic Performance of Engineering Students
}

\author{
Khaled Shaaban ${ }^{1 *}$, Ranya Reda ${ }^{2}$ \\ ${ }^{1}$ Associate Professor, Department of Engineering, Utah Valley University, Orem, Utah, USA \\ 2 Section Head of Learning Support, College of Engineering, Qatar University, Doha, QATAR
}

Received 16 October 2020 - Accepted 4 February 2021

\begin{abstract}
Students use different modes of transport to go to college. While many transportation programs exist at different universities and many experts find these programs to have a positive impact, no studies have investigated the impact of such programs on the absenteeism and academic performance of college students. The main purpose of this study is to investigate the impact of a college provided transportation program on the absenteeism and performance of engineering students. Different types of data were collected from a sample of engineering students, including attendance records, grade point average (GPA), course grades, majors, and bus ridership information for two years. The findings suggest that there is a positive impact of providing a college transportation service to engineering students in the form of better attendance and higher GPA. The outcomes of this study can be used to evaluate similar programs in the future and can be used by public agencies and policymakers to make decisions on expanding investments in such programs.
\end{abstract}

Keywords: education, transportation service, public transportation, attendance, college students

\section{INTRODUCTION}

Many researchers agree that attendance is important for the success of students in academics at the college level (Durden \& Ellis, 1995; Dolton, Marcenaro, \& Navarro et al., 2003; Kirby \& McElroy, 2003; Marburger, 2001). In addition, many students do not live close to their schools or colleges. A high percentage of these students depend on public transportation to reach their destination. Many schools and colleges provide transportation services for their students (Daggett \& Gutkowski, 2003). While many transportation programs exist at different institutes and many experts identify these programs to have a positive impact on attendance, no studies were identified related to investigating the impact of college provided transportation on absenteeism and performance. Therefore, there is a need for a thorough examination of such programs. In this study, real data were gathered from the largest university in Qatar, Qatar University (QU), to investigate the impact of the transportation service provided for engineering students on their attendance and academic achievement. The results from this study can be used to evaluate such programs and can be used by public agencies and policymakers to invest in or expand transportation services to students.

\section{LITERATURE REVIEW}

Grades are important to university students. Students with higher grades potentially have a higher chance of being employed and making higher salaries compared to students with poor grades (Bacon \& Bean, 2006; Kobrin et al., 2008; Poropat, 2009). Grade Point Average (GPA) is the most common indicator used to evaluate the performance of students during their years of study (Lounsbury et al., 2009; Richardson, M., Abraham, \& Bond, 2012). Most colleges have a minimum GPA for students to maintain as an indication of good standing. Usually, the same indicator is used as a criterion for acceptance in graduate programs. It is also used by employers as an indication of the students' competence and academic achievements in college (Plant et al., 2005; Strenze, 2007). The GPA for students is sometimes affected by grade inflation and differences

(c) 2021 by the authors; licensee Modestum. This article is an open access article distributed under the terms and conditions of the Creative Commons Attribution License (http://creativecommons.org/licenses/by/4.0/).

\kshaaban@uvu.edu (*Correspondence) $\square$ ranya@qu.edu.qa 


\section{Contribution to the literature}

- The study is one of the first efforts to explore the impact of a transportation service on students attendance and academic achievement.

- The results showed a positive impact in the form of better attendance and higher grade point average.

- The results suggest that investing in such services may help the students to improve their attendance and grades.

in grading systems between different universities (Johnson, 2006).

On the other hand, attendance is important for students at different levels. On the college level, there are very limited studies investigating the importance of attendance. On the high school level, different studies indicated students who attend school more have better grades and graduation records (Roby, 2004; Silver, Saunders, \& Zarate, 2008). Different studies focusing on student academic achievement in public schools showed that the attendance of students had a high impact on the performance of students in exams and test scores (Caldas, 1993; Lamdin, 1996) and that the absenteeism of students increased the educational gaps between the students (Balfanz \& Byrnes, 2012).

College students use different travel modes to reach their destination. In general, a travel mode is defined as the mode used to travel from a specific location to another. In this study, travel mode refers to the travel mode used by university students from their houses to the university. University students have unique characteristics compared to high-school students (Matthews \& Hamby, 1995). They have irregular schedules, socialize more, drive more, and make more trips (Limanond, Butsingkorn, \& Chermkhunthod, 2011)[20]. One study concluded that a lack of suitable and reasonable transportation means for students in schools could affect their attendance (Gase et al., 2014). Another study identified the positive influence of providing free student transit on the decrease of congestion and emissions (Pascal et al., 2013). One key reason identified by different studies as the main reason for being late to class is transportation and more specifically travel time reliability (Batley, Dargay, \& Wardman, 2011; Lomax \& Margiotta, 2003). On the high school level, studies identified the lack of proper transportation as the main reason for absenteeism (Baker, Sigmon, \& Nugent, 2001; Gase et al., 2014). When high-school students were provided with free passes to ride public transportation, absenteeism was reduced and academic performance was improved (Gase et al., 2014).

In summary, there are limited studies that evaluate transportation programs for universities in the literature. Furthermore, there are no clear indications that the mode of travel can affect academic performance and attendance for university students. The purpose of this study is to evaluate the impact of a transportation program on the academic achievement and attendance of students. The results from the study can be useful for policymakers to make decisions on expanding investments in such programs.

\section{METHODS}

\section{Case Study}

QU is the main national university in the state of Qatar. The university has only one campus and has a gender segregation policy to segregate male and female students on campus. The university has been one of the fastest-growing institutions in the Arabian Gulf region (Al Attiyah \& Khalifa, 2009). The number of male and female students in the College of Engineering has been steadily increasing over the past years. QU considers students' attendance as a crucial part of their learning experience and success. Accordingly, QU has a strict attendance policy. If a student misses more than $25 \%$ of the classes in a given course, he/she will receive a failing grade regardless of performance. Students with valid excuses are entitled to drop the course without fines. Instructors decide if a student is considered present or absent when only part of a class is attended. When instructors reschedule classes, they should obtain the consent of all students. Otherwise, students' absenteeism is not counted. Furthermore, attendance is not part of the students' assessment.

QU has its transportation system that offers various services to students. The service is operated and managed by the Transportation Services Office at QU and aims to ensure a quality and accessible transportation system for different needs. The transportation service started after the establishment of QU, and it is available for students, faculty, staff, and visitors at different levels. For students, transportation services accommodate different needs. One service is for special needs. This service provides free transportation services for all special needs students between various buildings and colleges. A second free service provides scientific and educational trips for all students who participate in various trips and activities. A third free service provides free internal transportation services for all students between various buildings and colleges. It operates five days a week (Sunday through Thursday) and starts from 7:30 am to 5:30 pm during business days as per the QU academic calendar. This service includes four different types of trips for female students and two for male students across the campus. Finally, the fourth 
Table 1. Bus Ridership and Fare

\begin{tabular}{|c|c|c|c|c|c|}
\hline School Year & $2012 / 2013$ & $2013 / 2014$ & $2014 / 2015$ & $2015 / 2016$ & $2016 / 2017$ \\
\hline Number of Students & 945 & 1104 & 1222 & 1299 & 1342 \\
\hline Semester Fare (QR) & 700 & 700 & 1000 & 1,000 & 1,000 \\
\hline Bus Ridership (\%) & $24.0 \%$ & $26.0 \%$ & $21.2 \%$ & $17.4 \%$ & $15.3 \%$ \\
\hline
\end{tabular}

service is a subsidized paid service that provides lowcost external transportation services for only female students who have difficulties in reaching the campus due to personal transportation issues. It should be noted that young female driving is limited in Qatar for different cultural and social reasons (Shaaban, 2019b; Shaaban, Gaweesh, \& Ahmed, 2018, 2020). This is the main reason for providing such service especially with the limited public transportation facilities in Qatar (Shaaban \& Hassan, 2014; Shaaban \& Kim, 2016; Shaaban \& Maher, 2019) and limited walking and cycling facilities (Shaaban, 2019a, 2020; Shaaban \& Abdur-Rouf, 2020). This transportation service is the focus of this study.

The home to university service operates five days a week; Sunday through Thursday during the fall and spring semesters. A limited number of courses are offered during the summer semester at QU. The student pays a subsidized fare of QR 1000 (approximately 274 US Dollars) per semester (15 weeks), which entitles the student to use all the trips scheduled on any school day. This amount is considered considerably low, especially that Qatar is a rich developing country (Shaaban, 2017). Four trips cover 63 areas inside and outside the city of Doha with a diameter of 50 kilometers. Two trips are arrival trips that reach the campus at 7:00 am and 11:00 $\mathrm{am}$. The other two are departure trips that leave the campus at 2:15 pm and 5:15 pm. In the case of arrival trips, the buses pick up students who live in far areas first and vice versa in the case of drop off.

The total number of buses in service is 50 buses. Three buses are used for educational trips. Seventeen buses (four for males and 13 females) are used for internal service. Finally, 30 buses are used for external service for the female students. Table 1 shows the number of female students using the external service and the bus fees during the four academic years from 2012 to 2017. As shown in Table 1, the bus ridership dropped from 21.2\% in $2014 / 2015$ to $15.3 \%$ in $2016 / 2017$. Many reasons may contribute to this drop. One might be the drop in the number of new admits to QU. Usually, freshmen do not possess a driving license due to age constraints (Shaaban \& Hassan, 2017). These students become potential users of the external transportation service. Another reason could be the increase in the semester fare from QR700 to QR1000.

\section{Data Collection}

A questionnaire was not used in the study since students may not recall their exact attendance or might be (consciously or unconsciously) reluctant to provide truthful answers due to the pressure of providing more socially acceptable (or aspirational) answers. Therefore, it was decided to collect actual data for this study. Extensive data were collected from different sources to provide actual records of attendance, performance, and bus usage.

Data were collected for the students taking a general popular course at QU, Engineering Skills and Ethics. The course is mandatory for all engineering students from all majors. It is designed to introduce students to the skills needed to succeed in college, introduce them to the different engineering disciplines, and explain the rules of ethics within the profession. During the course, students deal with study cases where they analyze ethical and non-ethical professional conduct. Furthermore, problem-solving, introduction to engineering design, and communication skills are covered in the course. The course is part of the mandatory college requirement for engineering majors. Although the course is an introductory level and meant to be taken in the first year of study, many students tend to take it during senior years. One of the reasons to select this specific course was to ensure having a sample that includes a variety of students at different stages of the college education.

The average number of students studying the course in a semester is 150 distributed in multiple sections depending on the number of students (average of 30 students per section). The course is taught twice a week for 15 weeks per semester for a total of 30 classes. All professors who taught the course in 2015 and 2016 were contacted. During the two years, the course was offered in 18 sections with a total number of students of 554 . The professors were asked to provide the attendance and performance data in their courses. Not all professors provided this information. The records for only eight sections were received, resulting in a total of 245 students.

The list of the students was sent to the Registration Office at QU to provide information regarding the students' GPA, nationality, and major. The GPA for the students was used as an indication of academic performance. Also, the Transportation Services at QU were contacted and asked to provide information regarding the students who used the bus service from the list of students. In this study, students' modes of travel to QU were divided into two types of modes (using the transportation bus provided by QU or using any other mode of travel such as walking, cycling, driving, carpooling, or taking public transportation). 
Table 2. Descriptive Statistics

\begin{tabular}{|c|c|c|c|}
\hline $\begin{array}{l}\text { Sample } \\
\text { Characteristics }\end{array}$ & Category & Frequency & Percent \\
\hline \multirow[t]{2}{*}{ Student Nationality } & Qatari & 108 & 44.1 \\
\hline & Other & 137 & 55.9 \\
\hline \multirow[t]{4}{*}{ Academic Period } & Spring 2015 & 24 & 9.8 \\
\hline & Fall 2015 & 58 & 23.7 \\
\hline & Spring 2016 & 73 & 29.8 \\
\hline & Fall 2016 & 90 & 36.7 \\
\hline \multirow[t]{2}{*}{ Bus Usage } & $\begin{array}{l}\text { Do not use bus } \\
\text { service }\end{array}$ & 194 & 79.2 \\
\hline & Use bus service & 51 & 20.8 \\
\hline \multirow[t]{8}{*}{ Final Grade } & A & 39 & 15.9 \\
\hline & B & 50 & 20.4 \\
\hline & $\mathrm{B}+$ & 35 & 14.3 \\
\hline & $\mathrm{C}$ & 24 & 9.8 \\
\hline & $\mathrm{C}+$ & 39 & 15.9 \\
\hline & $\mathrm{D}$ & 11 & 4.5 \\
\hline & $\mathrm{D}+$ & 21 & 8.6 \\
\hline & $\mathrm{F}$ & 26 & 10.6 \\
\hline \multirow[t]{2}{*}{ Absenteeism } & $10 \%$ or Less & 165 & 67.3 \\
\hline & More than $10 \%$ & 80 & 32.7 \\
\hline \multirow{2}{*}{$\begin{array}{l}\text { GPA at End of } \\
\text { Semester }\end{array}$} & Less than 2 & 47 & 19.2 \\
\hline & 2 or more & 198 & 80.8 \\
\hline Total & & 245 & 100.0 \\
\hline
\end{tabular}

\section{Logistic Regression}

Binary logistic regression was used in the analysis. This is an appropriate statistical technique when the independent variable is binary. It represents two groups of interest with values of 0 and 1 . The procedure for estimating coefficients is a maximum likelihood, and the goal is to find the best linear combination of independent variables to maximize the likelihood of obtaining the observed outcome frequencies (Hosmer Jr, Lemeshow, \& Sturdivant, 2013; Tabachnick \& Fidell, 2007). A binary logistic regression was applied to determine the effect of the bus usage on attendance, performance in the course, and the general GPA score. For example, the probability that a student does not miss more than $10 \%$ of the class is modeled as logistic distribution in the following form:

$$
P(\text { ClassAttendance })=\pi(x)=\frac{e^{g(x)}}{1+e^{g(x)}}
$$

Where $g(x)$ :

$$
\begin{gathered}
g(x)=\ln \left(\frac{\pi(x)}{1-\pi(x)}\right)=\beta_{0}+\beta_{1} x_{1}+\beta_{2} x_{2}+ \\
\beta_{3} x_{3}+\cdots+\beta_{n} x_{n}
\end{gathered}
$$

where $\pi(\mathrm{x})$ is the conditional probability of a student to attend the class. $x_{n}$ is independent variables. The independent variables can be either categorical or continuous, or a mixture of both. In this study, one independent variable was used, which is using the bus service or not. $\beta_{\mathrm{n}}$ is the model coefficient, which directly determines the odds ratio involved in using the service. The odds of an event are defined as the probability of the event occurring divided by the probability of the event not occurring. The odds ratio, which is equal to $\exp \left(\beta_{n}\right)$, tells the relative amount by which the odds of the outcome increase (odds ratio greater than 1.0) or decrease (odds ratio less than 1.0) when the value of the predictor value is increased by 1.0 units (Hosmer Jr \& Lemeshow, 2004). The analysis was conducted using the capabilities of the SPSS software.

\section{RESULTS}

\section{Descriptive Statistics}

Descriptive statistics were used to describe the distribution of the various variables. All participants were female since the service is only provided for them. As shown in Table 2, of the 245 students, $44.1 \%$ were Qatari nationals. The majority of the participants did not use the bus $(79.2 \%)$, which is in line with the population of female students using the bus, as shown in Table 1. About one-third of the participants (32.7\%) missed 10\% or more from the total classes of the course. Most of the students $(80.8 \%)$ had a GPA of 2 or more.

\section{T-test}

Afterward, the mean value for each group was computed as shown in Table 3. To check if the characteristics of the students who do not use the bus are significantly different from those who use the bus, an independent t-test was conducted. The null hypothesis was that the absenteeism, grade of the course, and GPA for the students who do not use the bus did not differ significantly from those who use the bus. As shown in Table 3, the independent t-test shows that the null hypothesis could be rejected at $95 \%$ confidence for the three different variables. Therefore, the absenteeism, grade of the course, and GPA for students differ significantly based on bus usage.

\section{Logistic Regression}

One of the main purposes of the study is to investigate the odds of different response variables occurring in students who use the bus service versus students who don't use it. The response variables (absenteeism of $10 \%$ or less, passing the course or not, and GPA of 2 or more) are binary (dichotomous) with two levels: 0 for No, and 1 for Yes. For the independent variables, one main categorical variable was included: bus usage $(0=$ do not use the bus service and $2=$ use the bus service. The SPSS program was used for model development, and the hypothesis testing was based on a 0.05 significant level. Table 4 shows the model estimation and the odds ratio for the independent variables. Bus usage showed a significant association with the three independent variables. The model showed that the odds of having absenteeism of $10 \%$ or less are 3.2 times higher for students who used the bus service than for those who did not use it. Also, the odds of passing the course are 7.4 times higher for students 
Table 3. T-test Statistics

Group Statistics

\begin{tabular}{|c|c|c|c|c|}
\hline Bus Usage & $\mathrm{N}$ & Mean & $\begin{array}{c}\text { Std. } \\
\text { Deviation }\end{array}$ & $\begin{array}{c}\text { Std. Error } \\
\text { Mean }\end{array}$ \\
\hline Attendance $(0=$ More than & 194 & 0.63 & 0.484 & 0.035 \\
\hline $10 \%, 1=10 \%$ or less) & 51 & 0.84 & 0.367 & 0.051 \\
\hline Final Grade $(0=$ Not pass, & 194 & 0.87 & 0.336 & 0.024 \\
\hline $1=$ Pass) & 51 & 0.98 & 0.140 & 0.020 \\
\hline GPA $(0=$ Less than 2 , & 194 & 0.78 & 0.416 & 0.030 \\
\hline 1=Two or more) & 51 & 0.92 & 0.272 & 0.038 \\
\hline
\end{tabular}

Independent Samples Test

Levene's Test for t-test for Equality of Means

Equality of Variances

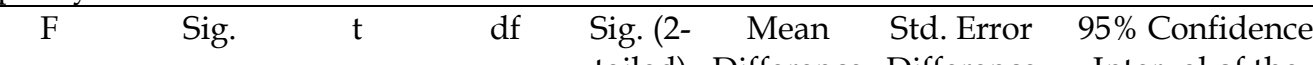
tailed) Difference Difference Interval of the

Difference

\begin{tabular}{|c|c|c|c|c|c|c|c|c|c|}
\hline & & & & & & & & Lower & Upper \\
\hline Attendance $(0=$ More than & 64.922 & 0.000 & -2.943 & 243 & 0.004 & -0.214 & 0.073 & -0.358 & -0.071 \\
\hline $10 \%, 1=10 \%$ or less) & & & -3.451 & 100.715 & 0.001 & -0.214 & 0.062 & -0.337 & -0.091 \\
\hline Final Grade $(0=$ Not pass, & 26.330 & 0.000 & -2.269 & 243 & 0.024 & -0.109 & 0.048 & -0.204 & -0.014 \\
\hline $1=$ Pass $)$ & & & -3.515 & 198.203 & 0.001 & -.109 & 0.031 & -0.171 & -0.048 \\
\hline GPA $(0=$ Less than 2, & 30.356 & 0.000 & -2.328 & 243 & 0.021 & -0.143 & 0.062 & -0.264 & -0.022 \\
\hline 1=Two or more) & & & -2.961 & 119.151 & 0.004 & -0.143 & 0.048 & -0.239 & -0.047 \\
\hline
\end{tabular}

Table 4. Logistic Model Results

\begin{tabular}{|c|c|c|c|c|c|c|c|c|}
\hline \multicolumn{9}{|c|}{ Absenteeism of $10 \%$ or Less } \\
\hline & \multirow{2}{*}{ B } & \multirow{2}{*}{ S.E. } & \multirow{2}{*}{ Wald } & \multirow{2}{*}{ df } & \multirow{2}{*}{ Sig. } & \multirow{2}{*}{$\operatorname{Exp}(B)$} & \multicolumn{2}{|c|}{ 95\% C.I. for EXP(B) } \\
\hline & & & & & & & Lower & Upper \\
\hline Bus_Usage(1) & 1.154 & .413 & 7.823 & 1 & .005 & 3.172 & 1.413 & 7.123 \\
\hline Constant & .527 & .149 & 12.592 & 1 & .000 & 1.694 & & \\
\hline \multicolumn{9}{|c|}{ Passing the Course } \\
\hline & \multirow{2}{*}{ B } & \multirow{2}{*}{ S.E. } & \multirow{2}{*}{ Wald } & \multirow{2}{*}{$\mathrm{df}$} & \multirow{2}{*}{ Sig. } & \multirow{2}{*}{$\operatorname{Exp}(B)$} & \multicolumn{2}{|c|}{ 95\% C.I. for EXP(B) } \\
\hline & & & & & & & Lower & Upper \\
\hline Bus_Usage(1) & 2.001 & 1.032 & 3.756 & 1 & .053 & 7.396 & 0.978 & 55.954 \\
\hline Constant & 1.911 & .214 & 79.535 & 1 & .000 & 6.760 & & \\
\hline \multicolumn{9}{|c|}{ GPA of 2.0 or More } \\
\hline & \multirow{2}{*}{ B } & \multirow{2}{*}{ S.E. } & \multirow{2}{*}{ Wald } & \multirow{2}{*}{$\mathrm{df}$} & \multirow{2}{*}{ Sig. } & \multirow{2}{*}{$\operatorname{Exp}(B)$} & \multicolumn{2}{|c|}{ 95\% C.I. for EXP(B) } \\
\hline & & & & & & & Lower & Upper \\
\hline Bus_Usage(1) & 1.208 & .549 & 4.844 & 1 & .028 & 3.346 & 1.141 & 9.810 \\
\hline Constant & 1.256 & .173 & 52.805 & 1 & .000 & 3.512 & & \\
\hline
\end{tabular}

who used the bus service than for those who did not use it. Furthermore, the model indicated that the odds of having a GPA of 2.0 or more are 3.3 times higher for students who used the bus service than for those who did not use it.

\section{CONCLUSION}

Academic performance is considered important for students because it is meaningful for universities and students due to its major impact on their opportunities for future employment (Figueiredo et al., 2017; Pinto \& Ramalheira, 2017). This paper presents one of the first efforts in investigating the impact of college provided transportation on the absenteeism and performance of students. The study used real data obtained from different sources. The findings suggest that there is a positive impact of providing transportation service to college students. This is indicated in the form of better attendance and higher GPA. The results suggest that an investment in the form of providing students with a reasonable form of transportation can help the students to improve their attendance and grades.

There are several limitations to this work. First, using a convenience sample by collecting the data of one course could miss some groups. However, it was not possible to include more courses due to the difficulty of collecting the data, especially data related to attendance. Another limitation was using a sample of female students only. Therefore, the results may not be representative of the whole population of students. However, it was not possible to collect data for male students since the service is only provided for female students. 
It is also important to acknowledge the need for additional studies of similar programs before promoting college transportation as a method to improve the attendance and performance of students. Additional university programs would need to be investigated in the future to make the results representative. Finally, it can be useful in the future to use a questionnaire to gather information from students regarding the impact of the bus service on attendance and performance at college.

Author contributions: All authors have sufficiently contributed to the study, and agreed with the results and conclusions.

Funding: No funding source is reported for this study.

Declaration of interest: No conflict of interest is declared by authors.

\section{REFERENCES}

Al Attiyah, A., \& Khalifa, B. (2009). Small steps lead to quality assurance and enhancement in Qatar University. Quality in Higher Education, 15(1), 29-38. https:// doi.org/10.1080/13538320902731609

Bacon, D. R., \& Bean, B. (2006). GPA in research studies: An invaluable but neglected opportunity. Journal of Marketing Education, 28(1), 35-42. https:/ / doi.org/ $10.1177 / 0273475305284638$

Baker, M. L., Sigmon, J. N., \& Nugent, M. E. (2001). Truancy Reduction: Keeping Students in School. Juvenile Justice Bulletin. https:// doi.org/10.1037/ e527782006-001

Balfanz, R., \& Byrnes, V. (2012). The importance of being in school: A report on absenteeism in the nation's public schools. The Education Digest, 78(2), 4.

Batley, R., Dargay, J., \& Wardman, M. (2011). The impact of lateness and reliability on passenger rail demand. Transportation Research Part E: Logistics and Transportation Review, 47(1), 61-72. https://doi.org /10.1016/j.tre.2010.07.004

Caldas, S. J. (1993). Reexamination of input and process factor effects on public school achievement. The Journal of Educational Research, 86(4), 206-214. https:/ / doi.org/10.1080/00220671.1993.9941832

Daggett, J., \& Gutkowski, R. (2003). University transportation survey: Transportation in university communities. Transportation Research Record: Journal of the Transportation Research Board, (1835), 42-49. https:// doi.org/10.3141/1835-06

Dolton, P., Marcenaro, O. D., \& Navarro, L. (2003). The effective use of student time: a stochastic frontier production function case study. Economics of Education Review, 22(6), 547-560. https://doi.org/ 10.1016/S0272-7757(03)00027-X

Durden, G. C., \& Ellis, L. V. (1995). The effects of attendance on student learning in principles of economics. The American Economic Review, 85(2), 343-346. https:/ / doi.org/10.1080/758518985
Figueiredo, H., Biscaia, R., Rocha, V., \& Teixeira, P. (2017). Should we start worrying? Mass higher education, skill demand and the increasingly complex landscape of young graduates' employment. Studies in Higher Education, 42(8), 1401-1420.

https:/ / doi.org/10.1080/03075079.2015.1101754

Gase, L. N., Kuo, T., Teutsch, S., \& Fielding, J. E. (2014). Estimating the costs and benefits of providing free public transit passes to students in Los Angeles County: Lessons learned in applying a health lens to decision-making. International Journal of Environmental Research and Public Health, 11(11), 11384-11397. https://doi.org/10.3390/ijerph111111384

Hosmer Jr, D. W., \& Lemeshow, S. (2004). Applied Logistic Regression. John Wiley \& Sons. https://doi.org/ 10.1002/0470011815.b2a10030

Hosmer Jr, D. W., Lemeshow, S., \& Sturdivant, R. X. (2013). Applied Logistic Regression. John Wiley \& Sons. https:/ / doi.org/10.1002/9781118548387

Johnson, V. E. (2006). Grade Inflation: A Crisis in College Education. Springer Science \& Business Media.

Kirby, A., \& McElroy, B. (2003). The effect of attendance on grade for first year economics students in University College Cork. The Economic and Social Review, 34(3), 311-326.

Kobrin, J. L., Patterson, B. F., Shaw, E. J., Mattern, K. D., \& Barbuti, S. M. (2008). Validity of the SAT® for Predicting First-Year College Grade Point Average. Research Report No. 2008-5. College Board.

Lamdin, D. J. (1996). Evidence of student attendance as an independent variable in education production functions. The Journal of Educational Research, 89((3), $155-162$. https:/ / doi.org/10.1080/00220671.1996.9941321

Limanond, T., Butsingkorn, T., \& Chermkhunthod, C. (2011). Travel behavior of university students who live on campus: A case study of a rural university in Asia. Transport Policy, 18(1), 163-171. https:/ / doi.org/10.1016/j.tranpol.2010.07.006

Lomax, T., \& Margiotta, R. (2003). Selecting Travel Reliability Measures. The Institute.

Lounsbury, J. W., Fisher, L. A., Levy, J. J., \& Welsh, D. P. (2009). An investigation of character strengths in relation to the academic success of college students. Individual Differences Research, 7(1).

Marburger, D. R. (2001). Absenteeism and undergraduate exam performance. The Journal of Economic Education, 32(2), 99-109. https://doi.org/ 10.1080/00220480109595176

Matthews, D. B., \& Hamby, J. V. (1995). A comparison of the learning styles of high school and college/university students. The Clearing House, 
68(4), 257-261. https://doi.org/10.1080/00098655. 1995.9957245

Pascal, M., Corso, M., Chanel, O., Declercq, C., Cesaroni, G., Henschel, S., ... Medina, S. (2013). Assessing the public health impacts of urban air pollution in 25 European cities: results of the Aphekom project. Science of the Total Environment, 449, 390-400. https:/ / doi.org/10.1016/j.scitotenv.2013.01.077

Pinto, L. H., \& Ramalheira, D. C. (2017). Perceived employability of business graduates: The effect of academic performance and extracurricular activities. Journal of Vocational Behavior, 99, 165-178. https:/ / doi.org/10.1016/j.jvb.2017.01.005

Plant, E. A., Ericsson, K. A., Hill, L., \& Asberg, K. (2005). Why study time does not predict grade point average across college students: Implications of deliberate practice for academic performance. Contemporary Educational Psychology, 30(1), 96-116. https:/ / doi.org/10.1016/j.cedpsych.2004.06.001

Poropat, A. E. (2009). A meta-analysis of the five-factor model of personality and academic performance. Psychological Bulletin, 135(2), 322. https://doi.org/ $10.1037 / \mathrm{a} 0014996$

Richardson, M., Abraham, C., \& Bond, R. (2012). Psychological correlates of university students' academic performance: a systematic review and meta-analysis. Psychological Bulletin, 138(2), 353. https://doi.org/10.1037/a0026838

Roby, D. E. (2004). Research on school attendance and student achievement: A study of Ohio schools. Educational Research Quarterly, 28(1), 3.

Shaaban, K. (2017). Assessment of Drivers' Perceptions of Various Police Enforcement Strategies and Associated Penalties and Rewards. Journal of Advanced Transportation, 14, Art no. 5169176. https:/ / doi.org/10.1155/2017/5169176

Shaaban, K. (2019a). Assessing Sidewalk and Corridor Walkability in Developing Countries. Sustainability, 11(14), 3865. https:/ / doi.org/10.3390/su11143865

Shaaban, K. (2019b). Self-Report and Observational Assessment and Investigation of Seat Belt Use Among Young Drivers and Passengers: The Case of Qatar. Arabian Journal for Science and Engineering, 44(5), 4441-4451. https://doi.org/10.1007/s13369018-3436-3

Shaaban, K. (2020). Why Don't People Ride Bicycles in High-Income Developing Countries, and Can Bike-
Sharing Be the Solution? The Case of Qatar. Sustainability, 12(4), 1693. https://doi.org/10.3390 / su12041693

Shaaban, K., \& Abdur-Rouf, K. (2020). Assessing Walking and Cycling around Schools. Sustainability, 12(24), 10607. https://doi.org/ $10.3390 /$ su122410607

Shaaban, K., \& Hassan, H. (2014). Modeling significant factors affecting Commuters' perspectives and propensity to use the new proposed metro service in Doha. Canadian Journal of Civil Engineering, 41(12), 1054-1064. https://doi.org/10.1139/cjce2013-0595

Shaaban, K., \& Hassan, H. M. (2017). Underage Driving and Seat Belts Use of High School Teenagers in Qatar. Journal of Transportation Safety $\mathcal{E}$ Security, 9(S1), 115-129. https://doi.org/10.1080/19439962. 2016.1212445

Shaaban, K., \& Kim, I. (2016). Assessment of the taxi service in Doha. Transportation Research Part A: Policy and Practice, 88, 223-235. https://doi.org/ 10.1016/j.tra.2016.04.011

Shaaban, K., \& Maher, A. (2019). Using the theory of planned behavior to predict the use of an upcoming public transportation service in Qatar. Case Studies on Transport Policy. https://doi.org/10.1016/ j.cstp.2019.11.001

Shaaban, K., Gaweesh, S., \& Ahmed, M. (2018). Characteristics and Mitigation Strategies for Cell Phone Use While Driving Among Young Drivers in Qatar. Journal of Transport $\mathcal{E}$ Health, 8, 6-14. https:// doi.org/10.1016/j.jth.2018.02.001

Shaaban, K., Gaweesh, S., \& Ahmed, M. M. (2020). Investigating in-vehicle distracting activities and crash risks for young drivers using structural equation modeling. PLoS One, 15(7), e0235325. https:// doi.org/10.1371/journal.pone.0235325

Silver, D., Saunders, M., \& Zarate, E. (2008). What factors predict high school graduation in the Los Angeles Unified School District. Policy Brief, 14.

Strenze, T. (2007). Intelligence and socioeconomic success: A meta-analytic review of longitudinal research. Intelligence, 35(5), 401-426. https:/ / doi.org/10.1016/j.intell.2006.09.004

Tabachnick, B. G., \& Fidell, L. S. (2007). Using Multivariate Statistics (5th Ed.). Needham Height, MA: Allyn \& Bacon.

\section{http://www.ejmste.com}

